\title{
Leaching Chalcopyrite with an Imidazolium-Based Ionic Liquid and Bromide
}

\author{
Marcelo Rodríguez ${ }^{1}$, Luís Ayala ${ }^{2}$, Pedro Robles ${ }^{3, *}$, Rossana Sepúlveda ${ }^{4}$, David Torres ${ }^{1,5}$, \\ Francisco Raul Carrillo-Pedroza ${ }^{6}$ (D), Ricardo I. Jeldres ${ }^{7}$ (i) and Norman Toro ${ }^{1,5, *}$ \\ 1 Departamento de Ingeniería Metalúrgica y Minas, Universidad Católica del Norte, Av. Angamos 610, \\ Antofagasta 1270709, Chile; marceloandres.ra@gmail.com (M.R.); david.Torres@sqm.com (D.T.) \\ 2 Faculty of Engineering and Architecture, Universidad Arturo Prat, Almirante Juan José Latorre 2901, \\ Antofagasta 1244260, Chile; luisayala01@unap.cl \\ 3 Escuela de Ingeniería Química, Pontificia Universidad Católica de Valparaíso, Valparaíso 2340000, Chile \\ 4 Departamento de Ingeniería en Metalurgia, Universidad de Atacama, Copiapó 1531772, Chile; \\ rossana.sepulveda@uda.cl \\ 5 Department of Mining, Geological and Cartographic Department, Universidad Politécnica de Cartagena, \\ 30203 Murcia, Spain \\ 6 Facultad de Metalurgia, Universidad Autónoma de Coahuila, Carretera 57 Km 5, \\ Monclova C.P. 25710, Mexico; raul.carrillo@uadec.edu.mx \\ 7 Departamento de Ingeniería Química y Procesos de Minerales, Universidad de Antofagasta, \\ Antofagasta 1270300, Chile; ricardo.jeldres@uantof.cl \\ * Correspondence: pedro.robles@pucv.cl (P.R.); ntoro@ucn.cl (N.T.); Tel.: +56-552-651-021 (P.R.)
}

Received: 10 December 2019; Accepted: 24 January 2020; Published: 27 January 2020

check for updates

\begin{abstract}
The unique properties of ionic liquids (ILs) drive the growing number of novel applications in different industries. The main features of ILs are high thermal stability, recyclability, low flash point, and low vapor pressure. This study investigated pure chalcopyrite dissolution in the presence of the ionic liquid 1-butyl-3-methylimidazolium hydrogen sulfate, [BMIm] $\mathrm{HSO}_{4}$, and a bromide-like complexing agent. The proposed system was compared with acid leaching in sulfate media with the addition of chloride and bromide ions. The results demonstrated that the use of ionic liquid and bromide ions improved the chalcopyrite leaching performance. The best operational conditions were at a temperature of $90^{\circ} \mathrm{C}$, with an ionic liquid concentration of $20 \%$ and $100 \mathrm{~g} / \mathrm{L}$ of bromide.
\end{abstract}

Keywords: leaching; chalcopyrite; ionic liquid; bromide

\section{Introduction}

Chalcopyrite $\left(\mathrm{CuFeS}_{2}\right)$ is the most important source of primary copper sulfides, representing about $70 \%$ of global copper reserves. The principal method for its processing is through pyrometallurgical procedures, which is highly efficient. Still, the high operational costs and restricted availability of energy and water make hydrometallurgical methods an attractive opportunity [1-5]. However, the slow dissolution rate in traditional sulfate-acid systems makes this challenging or even impracticable for industrial purposes. Chalcopyrite is the most refractory copper sulfide, so the leaching is even more gradual than other copper sulfides like chalcocite $\left(\mathrm{Cu}_{2} \mathrm{~S}\right)$ and bornite $\left(\mathrm{Cu}_{5} \mathrm{FeS}_{4}\right)[6,7]$.

Diverse studies have contemplated further methods for leaching chalcopyrite, including the use of alkaline glycine solution [8,9], black carbon [10], hydrogen peroxide in hydrochloric acid solutions [11], bacteria [12,13], chlorinated media [14], and ionic liquids [15]. Ionic liquids (ILs) are salts formed by an organic cation and an anion which can be organic or inorganic. They are found as liquids at low temperatures, having a wide range of operating temperatures [16]. Among their excellent properties are their high degree of thermal stability, wide electrochemical range, recyclability, low flammability, 
and low vapor pressure [17]. Additionally, they are adaptable to specific chemical tasks [18-21]. Relating with hydrometallurgy, ILs are considered "green reactive agents", and they have been applied to remove contaminants, extracting metal ions and additives by electrodeposition [19,22-30].

The application of ionic liquids in leaching is one of the most relevant advancements for the treatment of chalcopyrite. These compounds offer an environmentally friendly option since the operations involve lower temperatures, less energy consumption, and reduced acid use. They also have unique attributes as salts that melt at room temperature [22,31]. Hu et al. [31] studied the leaching of chalcopyrite with the addition of hydrogen peroxide as an oxidizing agent, and the ionic liquids 1-hexyl-3-methyl-imidazolium hydrogen sulfate ([hmim] $\left.\left[\mathrm{HSO}_{4}\right]\right)$, 1-ethyl-3-methylimidazolium hydrogen sulfate ([emim] $\left.\left[\mathrm{HSO}_{4}\right]\right)$, 1-octyl-3-methylimidazolium hydrogen sulfate ([omim] $\left[\mathrm{HSO}_{4}\right]$ ), and 1-butyl-3-methylimidazolium hydrogen sulfate ([bmim] $\left[\mathrm{HSO}_{4}\right]$ ). The authors obtained the highest copper dissolution of $98.3 \%$ with $10 \%(v / v)$ of IL $[\mathrm{hmim}]\left[\mathrm{HSO}_{4}\right]$ in an aqueous solution, with a particle size of under $45 \mu \mathrm{m}, 25 \%$ hydrogen peroxide as an oxidant, a temperature of $45{ }^{\circ} \mathrm{C}$, and a leaching time of $120 \mathrm{~min}$. Kuzmina et al. [32] studied chalcopyrite dissolution using the series 1-butylimidazolium hydrogen sulfate $\left(\left[\mathrm{HC}_{4} \mathrm{im}\right]\left[\mathrm{HSO}_{4}\right]\right)$, 1-butyl-3-methylimidazolium hydrogen sulfate ([bmim] $\left[\mathrm{HSO}_{4}\right]$ ), imidazolium hydrogen sulfate ([HHim] $\left.\left[\mathrm{HSO}_{4}\right]\right)$, ethyl ammonium hydrogen sulfate $\left(\left[\mathrm{N}_{0002}\right]\left[\mathrm{HSO}_{4}\right]\right)$, 1-butyl-3-methylimidazolium dicyanamide ([bmim] $\left.\left[\mathrm{N}(\mathrm{CN})_{2}\right]\right)$, 1-butylimidazolium nitrate $\left(\left[\mathrm{HC}_{4} \mathrm{im}\right]\left[\mathrm{NO}_{3}\right]\right)$, and 1-butyl-3-methylimidazolium acetate ([bmim][OAc]), and found that the best IL to leach chalcopyrite was 1-butylimidazolium hydrogen sulfate, although the recovery rate was low without an oxidizing agent. Lastly, the ionic liquid $[\mathrm{bmim}]\left[\mathrm{HSO}_{4}\right]$ has shown the best performance in leaching mineral species, including refractory ores and precious metals [33-35].

Whitehead et al. [35] employed the ionic liquid $[\mathrm{bmim}]\left[\mathrm{HSO}_{4}\right]$ to leach chalcopyrite, resulting in markedly superior performance in the rate of copper dissolution terms. The authors compared the ionic liquid system with the traditional ferric acid medium and obtained similar copper recoveries, but the system employing the ionic liquid was much faster in the initial stages of copper leaching. The system adopted by the authors included a base for comparison using $1 \mathrm{M} \mathrm{H}_{2} \mathrm{SO}_{4}$ at $70{ }^{\circ} \mathrm{C}$, which resulted in a dissolution of $23.3 \%$. On the other hand, with the use of the ionic liquid from $10 \%$ to $100 \%$ $(w / w)$, the dissolution rates were between $55.7 \%$ and $86.6 \%$. Dong et al. [15] evaluated the impact of the concentration of ionic liquid on chalcopyrite solution. The researchers obtained the best copper dissolution of $88 \%$ at $70{ }^{\circ} \mathrm{C}$, with an ionic liquid level of $60 \%$ and a partial oxygen pressure of $17 \mathrm{kPa}$.

The literature describes the ionic liquid $[\mathrm{bmim}]\left[\mathrm{HSO}_{4}\right]$ as a chalcopyrite leaching agent with the capacity to produce protons, which occurs according to the following disassociation reactions $[15,36]$ :

$$
\begin{gathered}
{[\mathrm{bmin}]^{+}\left[\mathrm{HSO}_{4}^{-}\right] \stackrel{\mathrm{k}}{\leftrightarrow}[\mathrm{bmin}]^{+}+\mathrm{H}^{+}+\mathrm{SO}_{4}^{2-}} \\
\mathrm{K}=\frac{\left.[\mathrm{bmim}]^{+}\right][\mathrm{H}]^{+}\left[\mathrm{SO}_{4}^{2-}\right]}{[\mathrm{bmim}]\left[\mathrm{HSO}_{4}^{-}\right]}
\end{gathered}
$$

The main characteristic of the ionic liquid $[\mathrm{bmim}]\left[\mathrm{HSO}_{4}\right]$ is the high decrease in the $\mathrm{pH}$ of the leaching solution. With concentrations of $[\mathrm{bmim}]\left[\mathrm{HSO}_{4}\right]$ of 0.02 to $5.10 \mathrm{~mol} / \mathrm{L}$, the $\mathrm{pH}$ of the solution decreases from 1.7 to -0.61 [15].

Another method to treat refractory ores is through halide systems (fluoride, chloride, bromide, iodide, and astatine), which have environmental advantages over the traditional system since they act as a substitute for cyanide in the leaching of gold and platinum. Leaching ores with halides is characterized by high kinetic rates, complex stability, and the regeneration of leaching agents, among other characteristics [37-44]. The excellent results reported with the addition of halides include the use of iodine in leaching copper and gold [45-47]. The successful use of chlorinated media has been widely reported with concentrates and other copper sulfide products $[14,48,49]$. 
Bromide is a possible substitute for cyanide for leaching gold and other precious metals [50-57], which can be complexed by the bromide ion $\left(\mathrm{Br}^{-}\right)$and oxidized by bromine $\left(\mathrm{Br}_{2}\right)$. The mechanism proceeds according to the following equations [44,50]:

$$
\begin{gathered}
2 \mathrm{Au}+3 \mathrm{Br}_{2}+2 \mathrm{Br}^{-} \rightarrow 2 \mathrm{AuBr}_{4}^{-} \\
\mathrm{Pt}+2 \mathrm{Br}_{2}+2 \mathrm{Br}^{-} \rightarrow \mathrm{PtBr}_{6}^{2-} \\
\mathrm{Pd}+\mathrm{Br}_{2}+2 \mathrm{Br}^{-} \rightarrow \mathrm{PdBr}_{4}^{2-}
\end{gathered}
$$

There are few publications on copper dissolution with bromide. Still, they are numerous enough to reveal that bromide systems are highly corrosive to metallic copper, being effective in leaching copper sulfides and concentrates. The copper corrosion in the presence of $\mathrm{CuBr}$ is an electrochemical process, and the general mechanism proposed is the following [58,59]:

$$
\mathrm{Cu}+\mathrm{Cu}^{2+}+2 \mathrm{Br}^{-} \rightarrow 2 \mathrm{CuBr}
$$

McDonald et al. [60] described the leaching of chalcopyrite with the addition of copper(II) and bromide/sodium bromide. The central conclusion raised by the authors was that a cupric bromide system is faster than a cupric chloride one. The mechanism proposed by McDonald et al. [60] involves the $\mathrm{Cu}(\mathrm{I})$ production as follows:

$$
\mathrm{CuFeS}_{2}+3 \mathrm{Cu}^{2+} \frac{\mathrm{NaBr}}{\mathrm{H}_{2} \mathrm{O}} \rightarrow 4 \mathrm{Cu}^{+}+\mathrm{Fe}^{2+}+2 \mathrm{~S}^{0} .
$$

On the other hand, the mechanism proposed by Han and Meng [61] described the dissolution of chalcopyrite by the following equation, and involve the $\mathrm{Cu}(\mathrm{II})$ production (represented by $\mathrm{CuSO}_{4}$ ):

$$
\mathrm{CuFeS}_{2}+5 / 2 \mathrm{Br}_{2}+3 / 2 \mathrm{H}_{2} \mathrm{SO}_{4}+1 / 6 \mathrm{Na}_{2} \mathrm{SO}_{4}+2 \mathrm{H}_{2} \mathrm{O} \leftrightarrow \mathrm{S}^{0}+5 \mathrm{Br}^{-}+\mathrm{CuSO}_{4}+1 / 3 \mathrm{NaFe}_{3}\left(\mathrm{SO}_{4}\right)_{2}(\mathrm{OH})_{6}+5 \mathrm{H}^{+} .
$$

The reactions shown above represent an ideal bromide system in sulfate media, but in the presence of nitrate ions, bromide reacts to form bromine. The mechanism is shown in the following reaction [61]:

$$
5 \mathrm{Br}^{-}+5 / 3 \mathrm{NO}_{3}^{-}+20 / 3 \mathrm{H}^{+} \leftrightarrow 5 / 2 \mathrm{Br}_{2}+5 / 3 \mathrm{NO}+10 / 3 \mathrm{H}_{2} \mathrm{O}
$$

The hydrometallurgical processing of copper sulfides is an interesting alternative to substitute the pyrometallurgical methods. This research displays the experimental results of leaching chalcopyrite with bromide and the ionic liquid 1-butyl-3-methylimidazolium hydrogen sulfate. The approach proposed in this paper represents a promising option, highlighting its effectiveness with refractory species, as well as environmental benefits.

\section{Materials and Methods}

\subsection{Chalcopyrite}

The chalcopyrite mineral was provided by the Michilla Mining Company (Antofagasta, Chile). The mineralogical composition was monitored by X-ray diffraction (XRD), using an automatic and computerized X-ray diffractometer (Bruker model Advance D8, Billerica, MA, USA). The results that appear in Figure 1 indicated that it was $99.9 \%$ chalcopyrite. The chemical analysis was performed by atomic emission spectrometry via induction-coupled plasma (ICP-AES). The chalcopyrite concentrate sample was digested using aqua regia and hydrofluoric acid. Table 1 shows the chemical composition obtained by ICP-OES; the difference between copper and iron determined the sulfur. The samples were ground in a porcelain mortar to reach sizes between 47 and $38 \mu \mathrm{m}$. The procedures were performed in 
the Applied Geochemistry Laboratory of the Department of Geological Sciences of the Universidad Católica del Norte.

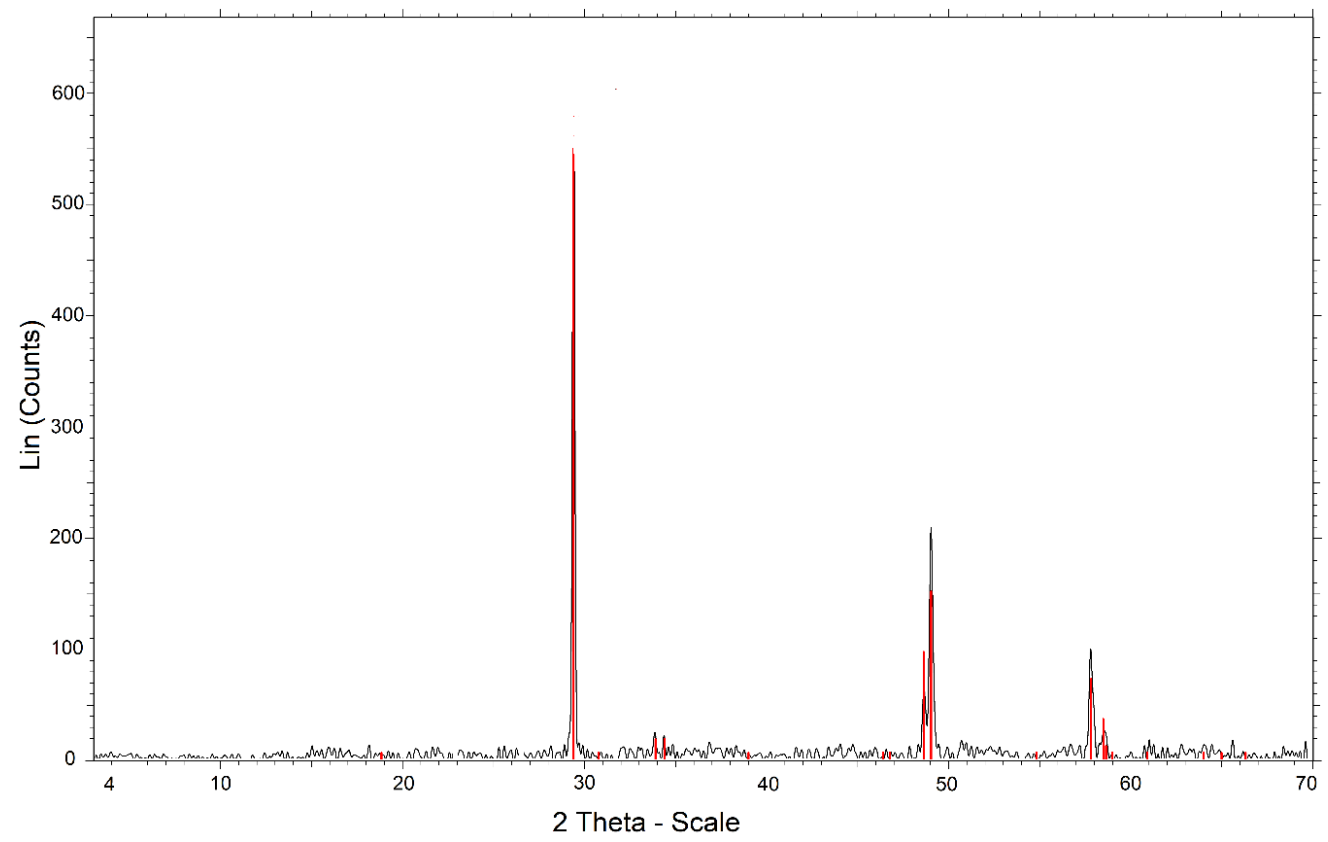

Figure 1. X-ray diffractogram of chalcopyrite ore.

Table 1. Chemical analysis of the sample.

\begin{tabular}{cccc}
\hline Element & $\mathbf{C u}$ & Fe & S \\
\hline Content $(\%)$ & 33.9 & 30.6 & 35.5 \\
\hline
\end{tabular}

\subsection{Leaching and Leaching Tests}

The lixiviant was prepared using the ionic liquid 1-butyl-3-methylimidazolium hydrogen sulfate (94.5-95\%, molecular weight of $236.29 \mathrm{~g} / \mathrm{mol}$, Sigma Aldrich) and sulfuric acid (95-97\%, P.A, Merck, the density of $1.84 \mathrm{~kg} / \mathrm{L}$ and molecular weight of $98.08 \mathrm{~g} / \mathrm{mol}$ ). Both reagents were dissolved in distilled water. The $\mathrm{NaCl}$ and $\mathrm{NaBr}$ were of analytical grade, from Merck.

\subsection{Leaching Test}

Leaching tests were carried out in a $50 \mathrm{~mL}$ glass reactor with a $0.01 \mathrm{~S} / \mathrm{L}$ ratio and an IL concentration of $20 \%(v / v)$ in an aqueous solution. Chalcopyrite ore $(200 \mathrm{mg})$ was kept in agitation and suspension with the use of a five-position magnetic stirrer (IKA ROS, CEP 13087-534, Campinas, Brazil) at $600 \mathrm{rpm}$. The temperature range tested in the experiments was $30-90{ }^{\circ} \mathrm{C}$ controlled by an oil-heated circulator (Julabo). All tests were duplicated, and the measurements (or analyses) were carried out in $5 \mathrm{~mL}$ aliquots and diluted using atomic absorption spectrometry (with a variation coefficient of $\leq 5 \%$ and a relative error of $5-10 \%)$. The $\mathrm{pH}$ and oxidation-reduction potential (ORP) of the leaching solutions were measured with a pH-ORP meter (HANNA HI-4222), by a combination of an ORP electrode cell composed of a platinum working electrode and a saturated $\mathrm{Ag} / \mathrm{AgCl}$ reference electrode.

\section{Results}

\subsection{Influence of Agitation Velocity}

Figure 2 gives the copper extraction from chalcopyrite at different mixing intensities. The optimal extraction rate (31\%) was obtained at $800 \mathrm{rpm}$. Agitating at 200 and $400 \mathrm{rpm}$, a portion of the particles 
settled, being unable to remain in the suspension, then the copper dissolution rates were low. The extraction rate was lower at $1000 \mathrm{rpm}$ than at 600 or $800 \mathrm{rpm}$ since part of the mineral was not homogenously agitated and adhered to the reactor wall. A previous study [62] argued that the essential factor is that the mineral particles can keep in suspension, rather than having a high mixing intensity.

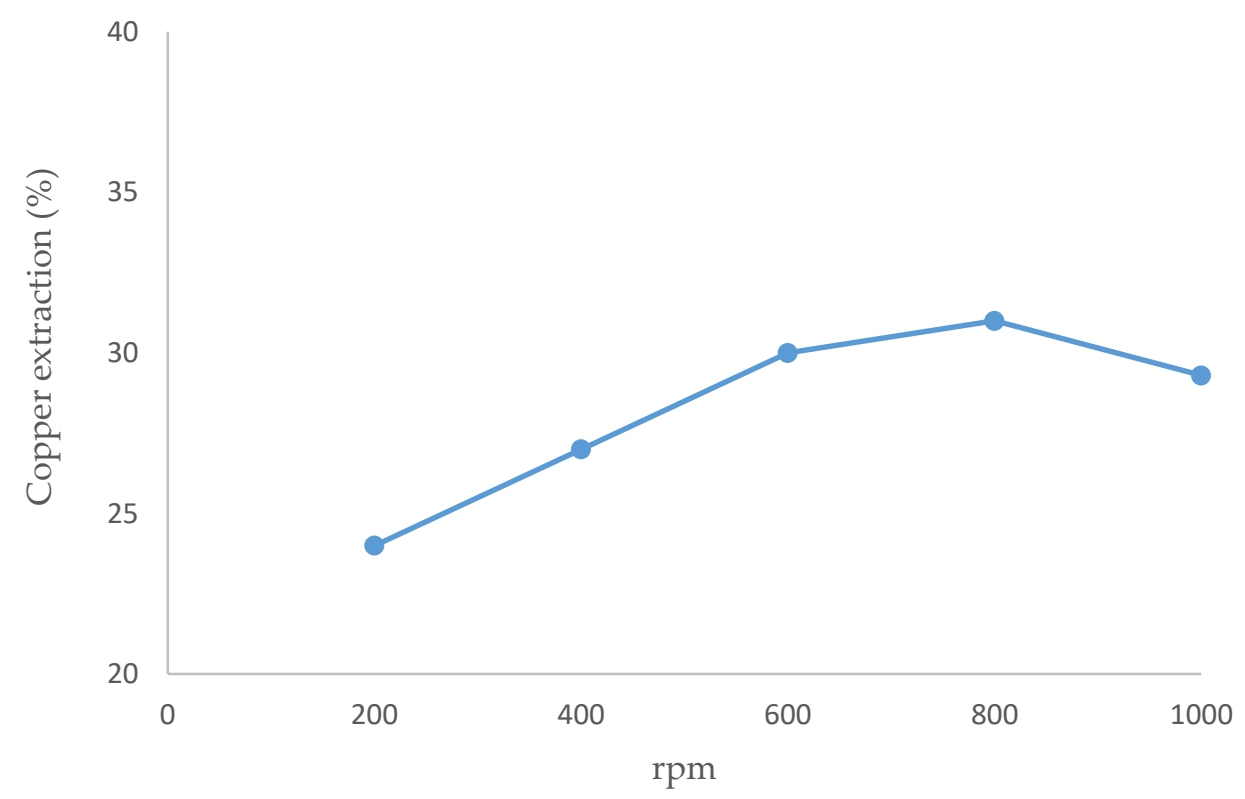

Figure 2. Effect of speed stirring on copper dissolution (temperature $80{ }^{\circ} \mathrm{C}, 20 \mathrm{~g} / \mathrm{L} \mathrm{of} \mathrm{Br}-, 20 \%(v / v)$ [bmim] $\left[\mathrm{HSO}_{4}\right]$, pulp density $10 \mathrm{~g} / \mathrm{L}, 24 \mathrm{~h}$ ).

\subsection{Effect on Chloride Concentration}

Figure 3 exhibits the differences in recovery rates over time for three cases: (i) a mixture of sulfuric acid and bromide, (ii) a mixture of sulfuric acid and chloride, and (iii) sulfuric acid alone. The best results were achieved for the mixture of sulfuric acid with chloride. Although no studies have used the same parameters, Encina and Aguayo [63], who worked with galena, concluded that leaching a $\mathrm{CuBr}_{2}-\mathrm{NaBr}$ system was faster than a copper-chloride system under the same conditions.

The inclusion of IL is compared in Figure 4. Three cases were studied: (i) IL alone, (ii) IL with bromide, and (iii) IL with chloride. The highest recovery rate was $86 \%$, obtained with the mixture between the IL and bromide. The recovery rate was lower with pure ionic liquid than with IL and sulfuric acid (Figure 3). A comparison of Figures 3 and 4 provide the differences between the two leaching agents $\left(\mathrm{H}_{2} \mathrm{SO}_{4}\right.$ and IL), with the addition of both halogens $\left(\mathrm{Cl}^{-}\right.$and $\left.\mathrm{Br}^{-}\right)$. Interestingly, the better extraction was achieved with ionic liquids considering bromide as an oxidizing agent $(86.0 \%)$. The opposite occurred with sulfuric acid, where better results were obtained with chloride (89.2\%). 


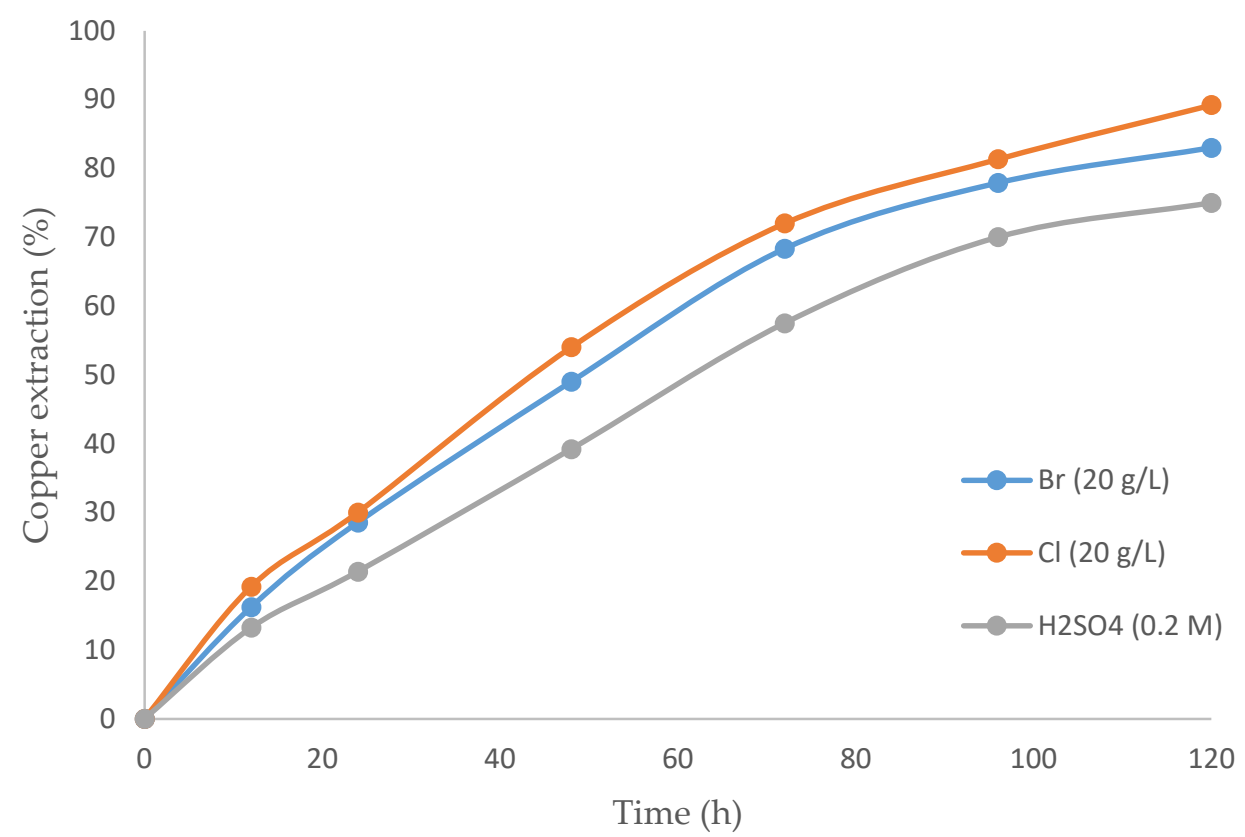

Figure 3. Copper extraction percentage over time (h) comparing: sulfuric acid with bromine, sulfuric acid with chloride, and only sulfuric acid (temperature $80{ }^{\circ} \mathrm{C}, 20 \%(v / v)[\mathrm{bmim}]\left[\mathrm{HSO}_{4}\right]$, pulp density $10 \mathrm{~g} / \mathrm{L})$.

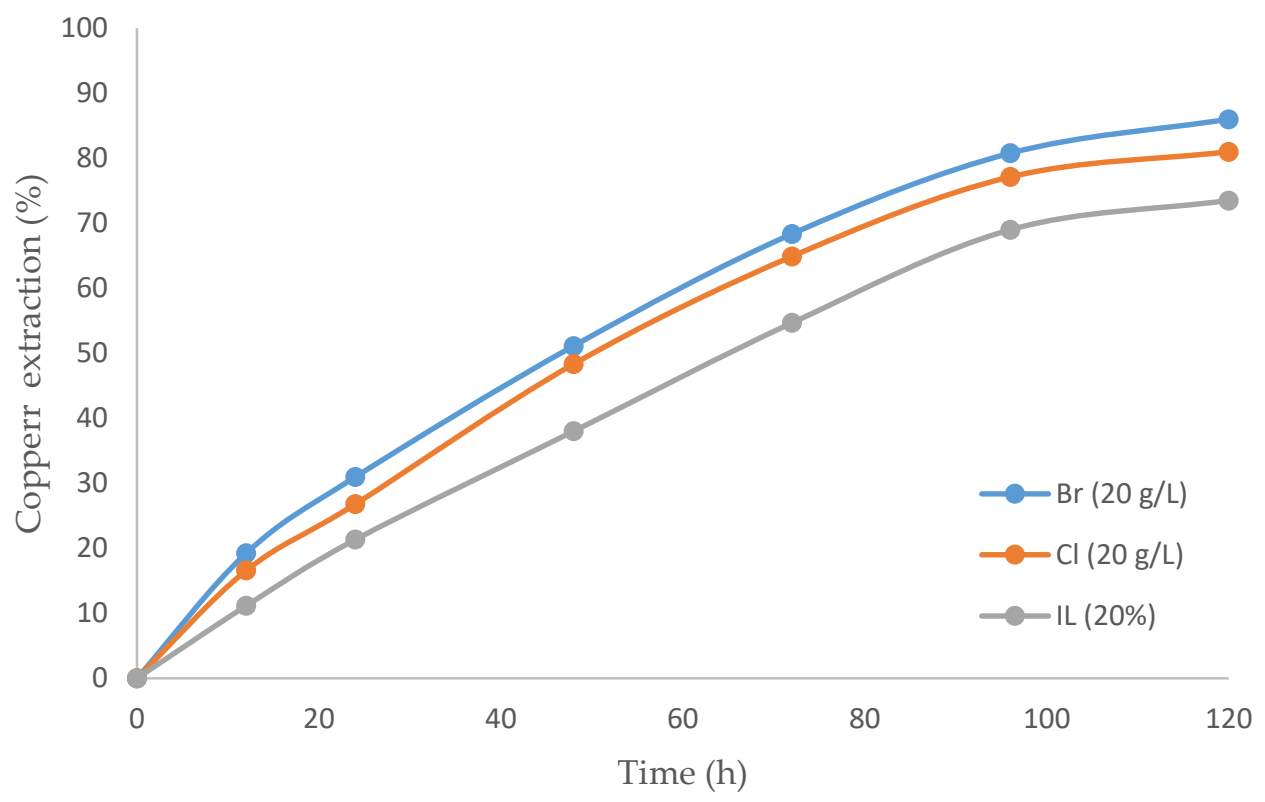

Figure 4. Copper extraction percentage over time (h) comparing: IL with bromine, IL with chloride, and only IL (temperature $80{ }^{\circ} \mathrm{C}, 20 \%(v / v)\left[b^{2} i m\right]\left[\mathrm{HSO}_{4}\right]$, pulp density $10 \mathrm{~g} / \mathrm{L}$ ).

\subsection{The Effect of Bromide on the Copper Extraction Rate}

Figure 5 presents the results of using a mixture of IL and bromide. As expected, the copper extraction rate was enhanced by increasing the concentration of bromide. The highest copper extraction was $83.6 \%$, obtained with $100 \mathrm{~g} / \mathrm{L}$ of bromide and a leaching time of $48 \mathrm{~h}$. Although no studies have presented the leaching of chalcopyrite with bromide, it should be noted that there are precedents with similar systems. Our results are similar to those of McDonald et al. [60], who pointed out the benefits 
of using bromide when dealing with sulfur minerals. Potential and $\mathrm{pH}$ levels were respectively in the ranges of 560 to $615 \mathrm{mV}$ and -1.0 to 0.4 in all the tests in this study.

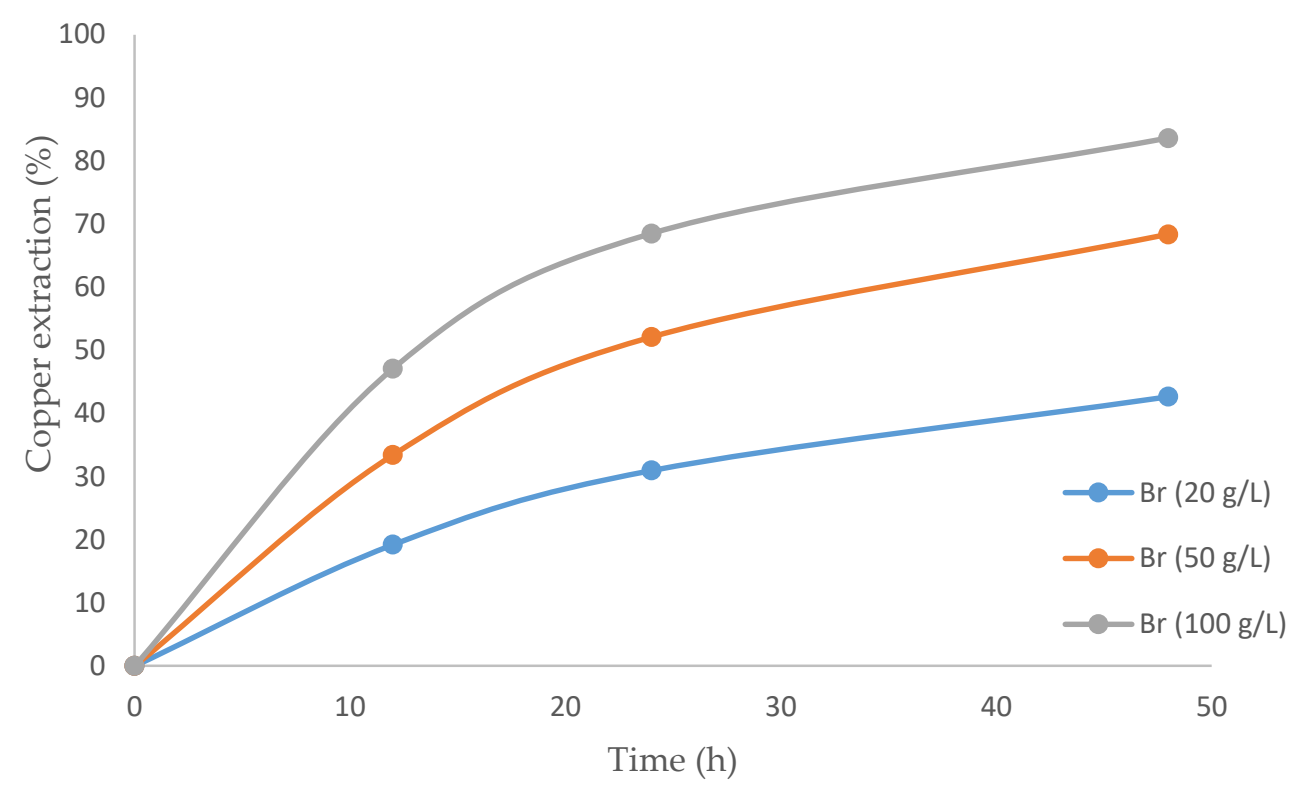

Figure 5. Graph of the copper extraction percentage over time using an ionic liquid and varying concentrations of bromide.

\subsection{Influence of Temperature on Copper Extraction Rates}

Figure 6 shows that copper extraction increased with higher temperatures. This can be explained by the fact that applying heat is the most effective way to provide sufficient activation energy to the molecules to increase the reaction kinetics. The velocity of the chemical reaction approximately doubled with every increase of $10{ }^{\circ} \mathrm{C}$ [64], and the highest copper extraction (84.6\%) was obtained at $90^{\circ} \mathrm{C}$ (maximum temperature in this work). The results were similar to those reported by Aguirre et al. [2], who worked with ionic liquid in chlorinated media.

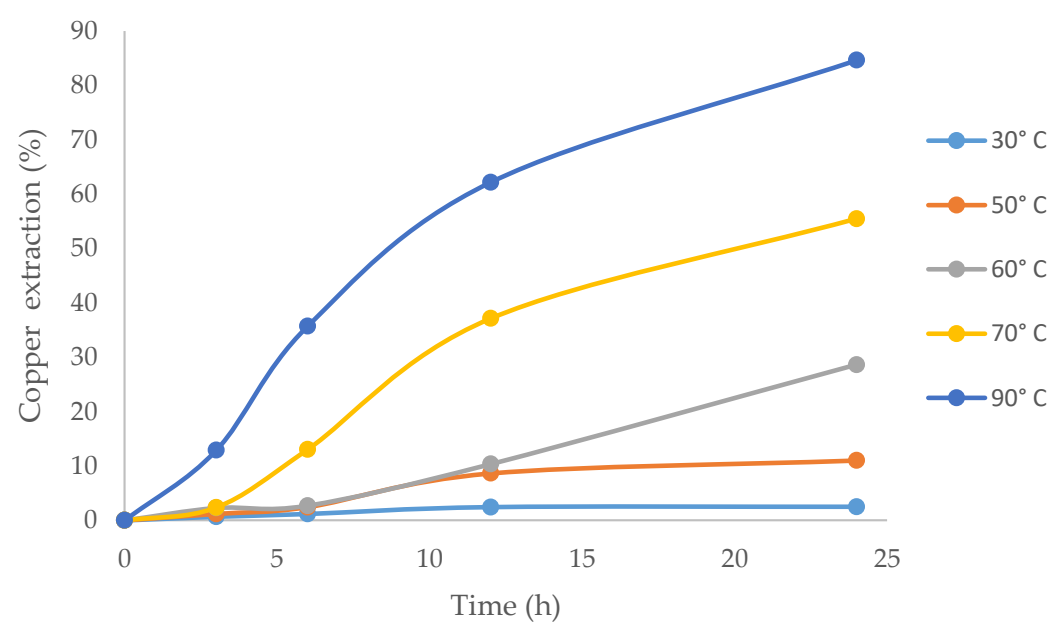

Figure 6. The effect of temperature on copper extraction from chalcopyrite using ionic liquid at $20 \%$ $(v / v)$ and $100 \mathrm{~g} / \mathrm{L}$ of $\mathrm{Br}^{-}$. 
The experimental data were analyzed deeply with the recessive nucleus model to control the surface reaction, for mono-sized particles, and explaining $\mathrm{Cu}$ extraction from $\mathrm{CuFeS}_{2}$ with the following equation:

$$
1-(1-x)^{\frac{1}{3}}=\mathrm{k}_{\mathrm{d}} \mathrm{t}
$$

where $x$ is the copper concentration in the solution over time, $\mathrm{k}_{\mathrm{d}}$ is the kinetic constant, and $t$ is the reaction time. The plot of the shrinking core model to explain the kinetic reaction mechanism is shown in Figure 7.

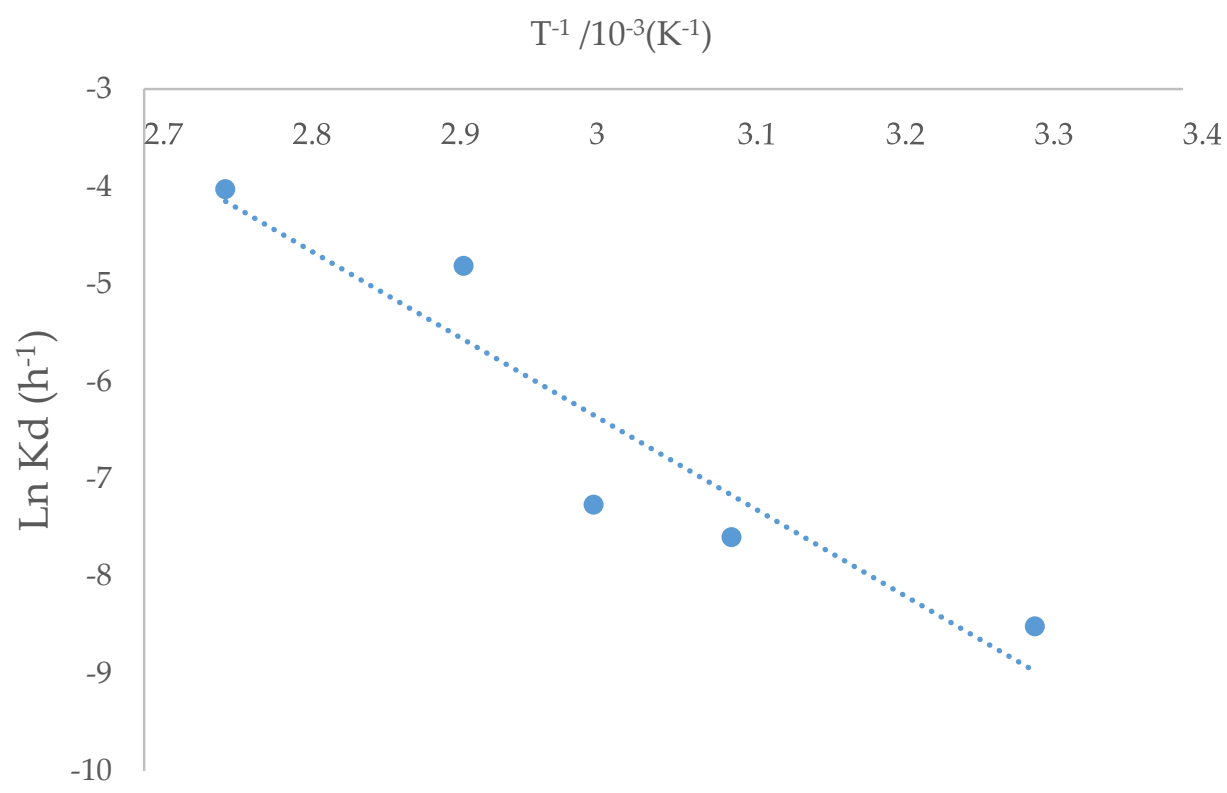

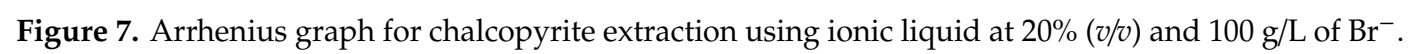

The kinetic constant $k_{d}$ for each temperature was obtained based on the slopes shown in Figure 7. The kinetics study showed that the shrinking core model was consistent with the experimental data. The Arrhenius graph (Figure 8) was obtained with the apparent kinetic constants $k_{d}$. The activation energy in the studied temperature range was $75.73 \mathrm{~kJ} / \mathrm{mol}$, similar to reported values for other IL systems [32]. The obtained results corroborate the proposed model for the system under study. On the other hand, the process is controlled by the chemical reaction and not by diffusive processes, this depending on the marked effect of temperature on kinetics.

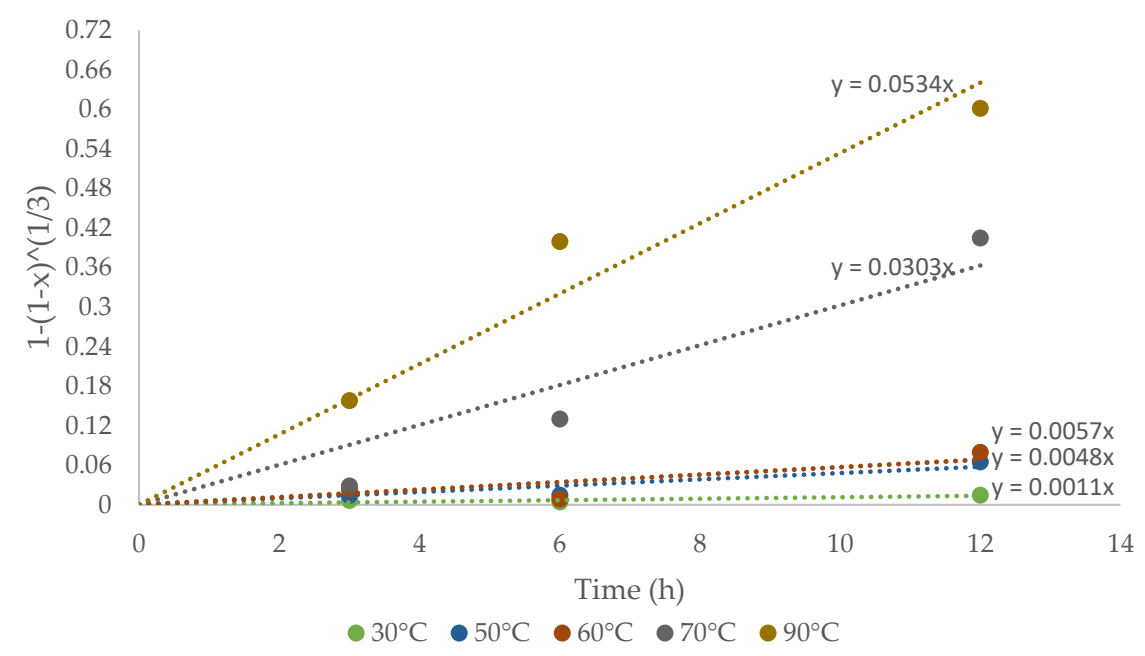

Figure 8. Plot of $1-(1-x)^{1 / 3}$ versus $\mathrm{CuFeS}_{2}$ dissolution time. 
Figure 9 shows the solution redox potential values over time for different temperatures. The potential varied between 570 and $600 \mathrm{mV}$ at temperatures of 30 and $50{ }^{\circ} \mathrm{C}$, where a first increase was found, followed by a decrease at the end, which reduced the copper dissolution kinetics. The potential at $60{ }^{\circ} \mathrm{C}$ moved between 590 and $610 \mathrm{mV}$, with copper extraction of 30\% after 24 h. No tendency toward mineral passivation was noted at this temperature, in contrast to what observed at 30 and $50{ }^{\circ} \mathrm{C}$. At 70 and $90^{\circ} \mathrm{C}$, the potential values located between 610 and $650 \mathrm{mV}$ and high rates of copper extraction (55\% and 85\%) were collected within $24 \mathrm{~h}$. Previous studies indicated that the typical potential range for leaching chalcopyrite is between 450 and $750 \mathrm{mV}[65,66]$. These values were optimized by Velásquez-Yévenes et al. [67], who worked with low chloride concentrations and a controlled potential. The authors stated that the appropriate potential range to leach chalcopyrite is between 550 and $620 \mathrm{mV}$. However, the potential values obtained in the present study differ from that range, considering that at higher concentrations of chloride, the potential range does not increase, because it is a complexing and non-oxidizing agent [67]. These results concur with those obtained in the present work, in which linear dissolution rates were obtained between 610 and $650 \mathrm{mV}$.

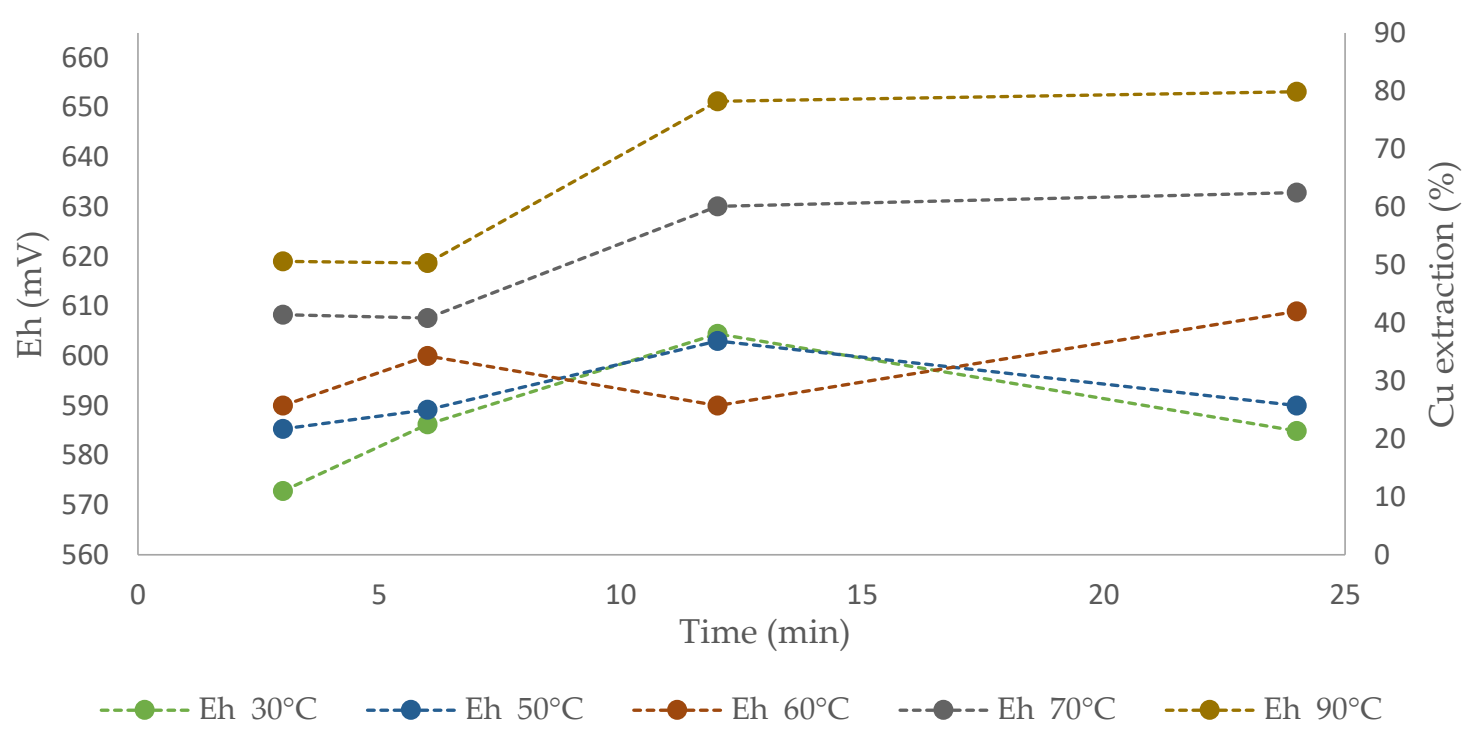

Figure 9. Effect of potential $\mathrm{Cu}$ extraction from $\mathrm{CuFeS}_{2}$ using ionic liquid at $20 \%(v / v)$ and $100 \mathrm{~g} / \mathrm{L}$ of $\mathrm{Br}^{-}$at temperatures of $30,50,60,70$, and $90^{\circ} \mathrm{C}$.

\section{Conclusions}

The present study exposes the consequences of leaching chalcopyrite using ionic liquid (1-butyl-3-methyl-imidazolium hydrogen sulfate) and sodium bromide. The assays were conducted to compare ionic liquid and sulfuric acid with the addition of halogens (bromide and chloride). The main findings were:

1. There was no significant improvement in $\mathrm{Cu}$ extractions by increasing the agitation rate of the system, and it was only necessary to keep the suspended particles dispersed.

2. When applying ionic liquid dissolved in water, the addition of bromide as an oxidant provided the best performance for the copper dissolution from chalcopyrite, while if sulfuric acid was used, the most suitable outcomes were achieved with chloride as an oxidant.

3. High concentrations of bromide in the system significantly reduced the necessary copper extraction.

4. The best results of this research were obtained at $90{ }^{\circ} \mathrm{C}$, with $20 \%(v / v)$ of ionic liquid, and $100 \mathrm{~g} / \mathrm{L}$ of bromide. The collected copper recovery was $85 \%$.

5. High concentrations of bromide $(100 \mathrm{~g} / \mathrm{L})$ raised the range of electrochemical potential suitable for leaching, with dissolution rates between 610 and $650 \mathrm{mV}$ at $90{ }^{\circ} \mathrm{C}$. 
Author Contributions: M.R. and R.S. contributed in research and wrote paper, N.T. and R.I.J. contributed in project administration, L.A., D.T. and P.R. contributed resources, P.R. contributed in review and editing and F.R.C.-P. contributed in data curing. All authors have read and agreed to the published version of the manuscript.

Funding: This research received no external funding.

Acknowledgments: The authors are grateful for the contribution of the Scientific Equipment Unit- MAINI of the Universidad Católica del Norte for facilitating the chemical analysis of the solutions. Pedro Robles thanks the Pontificia Universidad Católica de Valparaíso for the support provided. We also thank Conicyt Fondecyt 11,171,036 and Centro CRHIAM Project Conicyt/Fondap/15130015. Pedro Robles thanks the Pontificia Universidad Católica de Valparaíso for grants Project DI EMERGENTE-039.381/19.

Conflicts of Interest: The authors declare no conflict of interest.

\section{References}

1. Bobadilla-Fazzini, R.A.; Pérez, A.; Gautier, V.; Jordan, H.; Parada, P. Primary copper sulfides bioleaching vs. chloride leaching: Advantages and drawbacks. Hydrometallurgy 2017, 168, 26-31. [CrossRef]

2. Aguirre, C.L.; Toro, N.; Carvajal, N.; Watling, H.; Aguirre, C. Leaching of chalcopyrite (CuFeS2) with an imidazolium-based ionic liquid in the presence of chloride. Miner. Eng. 2016, 99, 60-66. [CrossRef]

3. Parada, F.; Jeffrey, M.I.; Asselin, E. Hydrometallurgy Leaching kinetics of enargite in alkaline sodium sulphide solutions. Hydrometallurgy 2014, 146, 48-58. [CrossRef]

4. Choubey, P.K.; Lee, J.; Kim, M.; Kim, H.S. Conversion of chalcopyrite to copper oxide in hypochlorite solution for selective leaching of copper in dilute sulfuric acid solution. Hydrometallurgy 2018, 178, 224-230. [CrossRef]

5. Baba, A.A.; Ayinla, K.I.; Adekola, F.A.; Ghosh, M.K.; Ayanda, O.S.; Bale, R.B.; Sheik, A.R.; Pradhan, S.R. A Review on Novel Techniques for Chalcopyrite Ore Processing. Int. J. Min. Eng. Miner. Process. 2012, 1, 1-16. [CrossRef]

6. Watling, H.R. Chalcopyrite hydrometallurgy at atmospheric pressure: 1. Review of acidic sulfate, sulfate-chloride and sulfate-nitrate process options. Hydrometallurgy 2013, 140, 163-180. [CrossRef]

7. Veloso, T.C.; Peixoto, J.J.M.; Pereira, M.S.; Leao, V.A. Kinetics of chalcopyrite leaching in either ferric sulphate or cupric sulphate media in the presence of $\mathrm{NaCl}$. Int. J. Miner. Process. 2016, 148, 147-154. [CrossRef]

8. Shin, D.; Ahn, J.; Lee, J. Kinetic study of copper leaching from chalcopyrite concentrate in alkaline glycine solution. Hydrometallurgy 2019, 183, 71-78. [CrossRef]

9. Eksteen, J.J.; Oraby, E.A.; Tanda, B.C. A conceptual process for copper extraction from chalcopyrite in alkaline glycinate solutions. Miner. Eng. 2017, 108, 53-66. [CrossRef]

10. Nakazawa, H. Effect of carbon black on chalcopyrite leaching in sulfuric acid media at $50{ }^{\circ} \mathrm{C}$. Hydrometallurgy 2018, 177, 100-108. [CrossRef]

11. PETROVIĆ, S.J.; BOGDANOVIĆ, G.D.; ANTONIJEVIĆ, M.M. Leaching of chalcopyrite with hydrogen peroxide in hydrochloric acid solution. Trans. Nonferrous Met. Soc. China 2018, 28, 1444-1455. [CrossRef]

12. Ma, L.; Wang, X.; Liu, X.; Wang, S.; Wang, H. Intensified bioleaching of chalcopyrite by communities with enriched ferrous or sulfur oxidizers. Bioresour. Technol. 2018, 268, 415-423. [CrossRef] [PubMed]

13. Esmailbagi, M.R.; Schaffie, M.; Kamyabi, A.; Ranjbar, M. Microbial assisted galvanic leaching of chalcopyrite concentrate in continuously stirred bioreactors. Hydrometallurgy 2018, 180, 139-143. [CrossRef]

14. Velásquez-Yévenes, L.; Torres, D.; Toro, N. Leaching of chalcopyrite ore agglomerated with high chloride concentration and high curing periods. Hydrometallurgy 2018, 181, 215-220. [CrossRef]

15. Dong, T.; Hua, Y.; Zhang, Q.; Zhou, D. Leaching of chalcopyrite with Brønsted acidic ionic liquid. Hydrometallurgy 2009, 99, 33-38. [CrossRef]

16. Wei, G.-T.; Yang, Z.; Chen, C.-J. Room temperature ionic liquid as a novel medium for liquid/liquid extraction of metal ions. Anal. Chim. Acta 2003, 488, 183-192. [CrossRef]

17. Keskin, S.; Kayrak-Talay, D.; Akman, U.; Hortaçsu, Ö. A review of ionic liquids towards supercritical fluid applications. J. Supercrit. Fluids 2007, 43, 150-180. [CrossRef]

18. Singh, V.; Kaur, S.; Sapehiyia, V.; Singh, J.; Kad, G.L. Microwave accelerated preparation of [bmim][HSO4] ionic liquid: An acid catalyst for improved synthesis of coumarins. Catal. Commun. 2005, 6, 57-60. [CrossRef]

19. Sepúlveda, R.; Romero, J.; Sánchez, J. Copper removal from aqueous solutions by means of ionic liquids containing a B-diketone and the recovery of metal complexes by supercritical fluid extraction. J. Chem. Technol. Biotechnol. 2014, 89, 899-908. [CrossRef] 
20. Quijada-Maldonado, E.; Romero, J.; Osorio, I. Selective removal of iron(III) from synthetic copper(II) pregnant leach solutions using [bmim][Tf2N] as diluent and TFA as extracting agent. Hydrometallurgy 2016, 159, 54-59. [CrossRef]

21. Janssen, C.H.C.; Macías-Ruvalcaba, N.A.; Aguilar-Martínez, M.; Kobrak, M.N. Metal extraction to ionic liquids: The relationship between structure, mechanism and application. Int. Rev. Phys. Chem. 2015, 34, 591-622. [CrossRef]

22. Park, J.; Jung, Y.; Kusumah, P.; Lee, J.; Kwon, K.; Lee, C.K. Application of ionic liquids in hydrometallurgy. Int. J. Mol. Sci. 2014, 15, 15320-15343. [CrossRef]

23. Liu, Y.; Guo, L.; Zhu, L.; Sun, X.; Chen, J. Removal of Cr(III, VI) by quaternary ammonium and quaternary phosphonium ionic liquids functionalized silica materials. Chem. Eng. J. 2010, 158, 108-114. [CrossRef]

24. Castillo, J.; Coll, M.T.; Fortuny, A.; Navarro Donoso, P.; Sepúlveda, R.; Sastre, A.M. Cu(II) extraction using quaternary ammonium and quaternary phosphonium based ionic liquid. Hydrometallurgy 2014, 141, 89-96. [CrossRef]

25. Valdés, H.; Sepúlveda, R.; Romero, J.; Valenzuela, F.; Sánchez, J. Near critical and supercritical fluid extraction of $\mathrm{Cu}$ (II) from aqueous solutions using a hollow fiber contactor. Chem. Eng. Process. Process. Intensif. 2013, 65, 58-67. [CrossRef]

26. Sun, X.; Ji, Y.; Zhang, L.; Chen, J.; Li, D. Separation of cobalt and nickel using inner synergistic extraction from bifunctional ionic liquid extractant (Bif-ILE). J. Hazard. Mater. 2010, 182, 447-452. [CrossRef]

27. Domańska, U.; Rękawek, A. Extraction of metal ions from aqueous solutions using imidazolium based ionic liquids. J. Solution Chem. 2009, 38, 739-751. [CrossRef]

28. Sepúlveda, R.; Castillo, J.; Plaza, A.; Sánchez, J.; Torres, A.; Romero, J. Improvement of recovery performance in the solvent extraction of $\mathrm{Cu}(\mathrm{II})$ using $[\mathrm{bmim}][\mathrm{Tf} 2 \mathrm{~N}]$ and a B-diketone as extractant and its stripping with supercritical carbon dioxide. J. Supercrit. Fluids 2017, 128, 26-31. [CrossRef]

29. Zhang, D.; Dong, L.; Li, Y.; Wu, Y.; Ma, Y.; Yang, B. Copper leaching from waste printed circuit boards using typical acidic ionic liquids recovery of e-wastes' surplus value. Waste Manag. 2018, 78, 191-197. [CrossRef]

30. Huang, J.; Chen, M.; Chen, H.; Chen, S.; Sun, Q. Leaching behavior of copper from waste printed circuit boards with Brønsted acidic ionic liquid. Waste Manag. 2014, 34, 483-488. [CrossRef]

31. Hu, J.; Tian, G.; Zi, F.; Hu, X. Leaching of chalcopyrite with hydrogen peroxide in 1-hexyl-3-methyl-imidazolium hydrogen sulfate ionic liquid aqueous solution. Hydrometallurgy 2017, 169, 1-8. [CrossRef]

32. Kuzmina, O.; Symianakis, E.; Godfrey, D.; Albrecht, T.; Welton, T. Ionic liquids for metal extraction from chalcopyrite: Solid, liquid and gas phase studies. Phys. Chem. Chem. Phys. 2017, 19, 21556-21564. [CrossRef]

33. Rüssen, A.; Topçu, M.A. Investigation of an alternative chemical agent to recover valuable metals from anode slime. Chem. Pap. 2018, 72, 2879-2891. [CrossRef]

34. Whitehead, J.A.; Lawrance, G.A.; McCluskey, A. “Green” leaching: Recyclable and selective leaching of gold-bearing ore in an ionic liquid. Green Chem. 2004, 6, 313-315. [CrossRef]

35. Whitehead, J.A.; Zhang, J.; Pereira, N.; McCluskey, A.; Lawrance, G.A. Application of 1-alkyl-3-methyl-imidazolium ionic liquids in the oxidative leaching of sulphidic copper, gold and silver ores. Hydrometallurgy 2007, 88, 109-120. [CrossRef]

36. Crowhurst, L.; Mawdsley, P.R.; Perez-Arlandis, J.M.; Salter, P.A.; Welton, T. Solvent-solute interactions in ionic liquids. Phys. Chem. Chem. Phys. 2003, 5, 2790-2794. [CrossRef]

37. Hilson, G.; Monhemius, A.J. Alternatives to cyanide in the gold mining industry: What prospects for the future? J. Clean. Prod. 2006, 14, 1158-1167. [CrossRef]

38. Lampinen, M.; Seisko, S.; Forsström, O.; Laari, A.; Aromaa, J.; Lundström, M.; Koiranen, T. Mechanism and kinetics of gold leaching by cupric chloride. Hydrometallurgy 2017, 169, 103-111. [CrossRef]

39. Seisko, S.; Lampinen, M.; Aromaa, J.; Laari, A.; Koiranen, T.; Lundström, M. Kinetics and mechanisms of gold dissolution by ferric chloride leaching. Miner. Eng. 2018, 115, 131-141. [CrossRef]

40. Ibáñez, T.; Velásquez, L. Lixiviación de la calcopirita en medios clorurados. Rev. Metal. 2013, 49, $131-144$. [CrossRef]

41. Ahtiainen, R.; Lundström, M.; Liipo, J. Preg-robbing verification and prevention in gold chloride-bromide leaching. Miner. Eng. 2018, 128, 153-159. [CrossRef]

42. Konyratbekova, S.S.; Baikonurova, A.; Akcil, A. Non-cyanide leaching processes in gold hydrometallurgy and iodine-iodide applications: A review. Miner. Process. Extr. Metall. Rev. 2015, 36, 198-212. [CrossRef] 
43. Hojo, M.; Yamamoto, M.; Maeda, T.; Kawano, H.; Okamura, K. Pure gold dissolution in dilute chloric, bromic or iodic acid solution containing abundant halide ions. J. Mol. Liq. 2017, 227, 295-302. [CrossRef]

44. Mpinga, C.N.; Eksteen, J.J.; Aldrich, C.; Dyer, L. Direct leach approaches to Platinum Group Metal (PGM) ores and concentrates: A review. Miner. Eng. 2015, 78, 93-113. [CrossRef]

45. Granata, G.; Miura, A.; Liu, W.; Pagnanelli, F.; Tokoro, C. Iodide-assisted leaching of chalcopyrite in acidic ferric sulfate media. Hydrometallurgy 2019, 186, 244-251. [CrossRef]

46. Baghalha, M. The leaching kinetics of an oxide gold ore with iodide/iodine solutions. Hydrometallurgy 2012, 113-114, 42-50. [CrossRef]

47. Konyratbekova, S.S.; Baikonurova, A.; Ussoltseva, G.A.; Erust, C.; Akcil, A. Thermodynamic and kinetic of iodine-iodide leaching in gold hydrometallurgy. Trans. Nonferrous Met. Soc. China 2015, 25, 3774-3783. [CrossRef]

48. Castillo, J.; Sepúlveda, R.; Araya, G.; Guzmán, D.; Toro, N.; Pérez, K.; Rodríguez, M.; Navarra, A. Leaching of white metal in a NaCl- $\mathrm{H}_{2} \mathrm{SO}_{4}$ system under environmental conditions. Minerals 2019, 9, 319. [CrossRef]

49. Hidalgo, T.; Kuhar, L.; Beinlich, A.; Putnis, A. Kinetic study of chalcopyrite dissolution with iron(III) chloride in methanesulfonic acid. Miner. Eng. 2018, 125, 66-74. [CrossRef]

50. Sousa, R.; Futuro, A.; Fiúza, A.; Vila, M.C.; Dinis, M.L. Bromine leaching as an alternative method for gold dissolution. Miner. Eng. 2018, 118, 16-23. [CrossRef]

51. Yoshimura, A.; Takai, M.; Matsuno, Y. Novel process for recycling gold from secondary sources: Leaching of gold by dimethyl sulfoxide solutions containing copper bromide and precipitation with water. Hydrometallurgy 2014, 149, 177-182. [CrossRef]

52. Zhang, Y.; Liu, S.; Xie, H.; Zeng, X.; Li, J. Current status on leaching precious metals from waste printed circuit boards. Procedia Environ. Sci. 2012, 16, 560-568. [CrossRef]

53. Yu, H.; Zi, F.; Hu, X.; Zhong, J.; Nie, Y.; Xiang, P. The copper-ethanediamine-thiosulphate leaching of gold ore containing limonite with cetyltrimethyl ammonium bromide as the synergist. Hydrometallurgy 2014, 150, 178-183. [CrossRef]

54. van Meersbergen, M.T.; Lorenzen, L.; van Deventer, J.S.J. The electrochemical dissolution of gold in bromine medium. Miner. Eng. 1993, 6, 1067-1079. [CrossRef]

55. Hojo, M.; Iwasaki, S.; Okamura, K. Pure gold dissolution with hydrogen peroxide as the oxidizer in $\mathrm{HBr}$ or HI solution. J. Mol. Liq. 2017, 246, 372-378. [CrossRef]

56. Dadgar, A. Refractory concentrate gold leaching: Cyanide vs. bromine. JOM 1989, 41, 37-41. [CrossRef]

57. Encinas-Romero, M.A.; Tiburcio-Munive, G.; Yanez-Montano, M. A Kinetic Study of Gold Leaching in CuBr2-NaBr system. J. Multidiscip. Eng. Sci. Technol. 2015, 2, 2118-2121.

58. Hibbert, D.B.; Richards, S.; Gonzalves, V. The kinetics and mechanism of the corrosion of copper in acidified copper (II) bromide solution. Corros. Sci. 1990, 30, 367-376. [CrossRef]

59. Brolo, A.G.; Temperini, M.L.A.; Agostinho, S.M.L. Copper dissolution in bromide medium in the absence and presence of hexamethylenetetramine (HMTA). Electrochim. Acta 1998, 44, 559-571. [CrossRef]

60. McDonald, G.W.; Darus, H.; Langer, S.H. A cupric bromide process for hydrometallurgical recovery of copper. Hydrometallurgy 1990, 24, 291-316. [CrossRef]

61. Han, K.N.; Meng, X. Recovery of copper from its sulfides and other sources using halogen reagents and oxidants. Mining, Metall. Explor. 2003, 20, 160-164. [CrossRef]

62. Toro, N.; Saldaña, M.; Castillo, J.; Higuera, F.; Acosta, R. Leaching of manganese from marine nodules at room temperature with the use of sulfuric acid and the addition of tailings. Minerals 2019, 9, 289. [CrossRef]

63. Encinas-Romero, M.A.; Aguayo-Salinas, S. Cupric Bromide Process for the Leaching of Galena. In Proceedings of the Second Conference in Hydrometallurgy, Changsha, China, 1993; pp. 227-230.

64. Zabala, M. Comportamiento de la recuperación de cobre en una pila de lixiviación a condiciones ambientales extremas. Master's Thesis, Pontificia Universidad Católica De Valparaíso, Valparaiso, Chile, 30 December 2013.

65. Nicol, M.; Miki, H.; Velásquez-Yévenes, L. The dissolution of chalcopyrite in chloride solutions: Part 3. Mechanisms. Hydrometallurgy 2010, 103, 86-95. [CrossRef]

66. Nicol, M.; Basson, P. The anodic behaviour of covellite in chloride solutions. Hydrometallurgy 2017, 172, 60-68. [CrossRef] 
67. Yévenes, L.V.; Miki, H.; Nicol, M. The dissolution of chalcopyrite in chloride solutions: Part 2: Effect of various parameters on the rate. Hydrometallurgy 2010, 103, 80-85. [CrossRef]

(C) 2020 by the authors. Licensee MDPI, Basel, Switzerland. This article is an open access article distributed under the terms and conditions of the Creative Commons Attribution (CC BY) license (http://creativecommons.org/licenses/by/4.0/). 